\title{
Physiological Responses of Chickpea Genotypes under Varying Salinity Levels
}

\author{
Neelam* and Neeraj Kumar \\ Department of Botany and Plant Physiology, CCS Haryana Agricultural University, \\ Hisar-125004, Haryana, India \\ *Corresponding author
}

\begin{abstract}
A B S T R A C T
Keywords

Chickpea,

Genotypes,

Physiological and salinity

Article Info

Accepted:

16 December 2017

Available Online:

10 January 2018

A pot experiment was conducted under natural conditions of screen house to evaluate the effect of saline irrigation given at flowering stage on plant water status functioning and their tolerance in two chickpea (Cicer arietinum) genotypes viz. HC-3 and CSG-8962. The pots containing dune sand were saturated with $\mathrm{Cl}^{-}$dominated saline irrigation at (40-45 DAS) to maintain $\mathrm{EC}_{\mathrm{iw}}$ of $2.0,4.0$ and $6.0 \mathrm{dS} \mathrm{m} \mathrm{m}^{-1}$ as compared to control. The control plants were irrigated with distilled water. The water potential $\left(\Psi_{\mathrm{w}}\right)$ of leaves, osmotic potential $\left(\Psi_{\mathrm{s}}\right)$ of leaves and roots and RWC of leaves and roots decreased significantly with increase in saline irrigation level from control to $6.0 \mathrm{dS} \mathrm{m}^{-1}$ at flowering stage.HC-3 showed more decline in water potential of leaves and osmotic potential of leaves and roots and RWC of leaves and rootsas compared to CSG-8962. Hence, the mechanism of salt tolerance was comparatively better in the HC-3 than in CSG-8962 as found from the physiological traits studied.
\end{abstract}

\section{Introduction}

Salt stress in soil or water is one of the major abiotic stresses limiting crop productivity and affecting about 95 million hectares of land worldwide. Whereas, in India, salt affected soil is about 6.73 Mha consisting of nearly 2.96 mha saline and 3.77 mha sodic soil. Salinity limited the growth and development of plant by altering their morphological and physiological attributes and production in most of the arid and semi-arid regions of the world (Kandil et al., 2012). Crops growing in arid and semi-arid regions suffer tremendously due to insufficient and regular distribution of precipitation as a result of which the crop plants relies extensively on irrigation water and a considerable proportion of underground water in most of these regions is of poor quality hence, immensely affecting the growth and yield of different agricultural crops in such areas.

Chickpea is an important pulse crop growing in arid and semi-arid regions of the country but owing to poor quality of water/ soil, the productivity of this crop is not optimal under such conditions. Chickpea (Cicer arietinum), belonging to family Fabaceae, is an ancient self-pollinated leguminous crop growing since 
$7000 \mathrm{BC}$, in different area of the world (Tekeoglu et al., 2000) but its cultivation is mainly concentrated in arid and semi-arid environments such South Asia, West Asia, North Africa, East Africa, Southern Europe, North and South America, and Australia (Arefian et al., 2014; Flowers et al., 2010). Chickpea acquires its importance as source of food for both humans as well as for livestock. Chickpea plays an important role in nitrogen fixation and hence, helps in maintaining soil fertility, particularly in the arid and low rainfall area (Roy et al., 2010).

In recent decades considerable improvements with respect to morphological and physiological traits have been made in different agricultural crops for salinity tolerance. However, not much findings have been reported for salinity tolerance in chickpea. Hence, the present investigation was conducted to study the physiological responses of different chickpea varieties under varying levels of salinity.

\section{Materials and Methods}

The study was conducted in the screen house at the Department of Plant, Physiology, CCS Haryana Agricultural University, Hisar. The study consisted of two chickpea genotypes i.e. CSG-8962 (salt tolerant) and HC-3 grown in pots filled with the dune sand $93.3 \%$ sand + $3.0 \%$ slit $+3.7 \%$ clay, saturation capacity 25 $\%, \mathrm{pH} 8.2, \mathrm{ECe}_{2} 0.8 \mathrm{dS} \mathrm{m}^{-1}$ at $25^{\circ} \mathrm{C}, 10.3 \mathrm{mg}$ (N) $\left.\mathrm{kg}^{-1}, 2.5 \mathrm{mg}(\mathrm{P}) \mathrm{kg}^{-1}, 180 \mathrm{mg}(\mathrm{K}) \mathrm{kg}^{-1}\right)$. The seeds before sowing were surface sterilized and were inoculated with effective Rhizobium culture (Ca 181).

Each pot was supplied with equal quantity of $\mathrm{N}_{2}$ free nutrient solution at a regular interval of 15 days. The chloride dominated Hoagland solutions were prepared by using chloride salts of $\mathrm{Na}^{+}, \mathrm{Ca}^{2+}, \mathrm{Mg}^{2+}$ and sulfate salt of $\mathrm{Mg}$. Four salinity levels (control, 2.0, 4.0 and 6.0
dS $\mathrm{m}^{-1}$ ) were applied at 40-45 days after sowing (DAS) with $\mathrm{Na}\left(\mathrm{Ca}^{2+}+\mathrm{Mg}^{2+}\right)$ and $\mathrm{Ca}^{2+}: \mathrm{Mg}^{2+}$ ratio at $1: 1$ and $1: 3$, respectively, whereas $\mathrm{Cl}: \mathrm{SO}_{4}{ }^{2-}$ was maintained at 7:3 ratio. While, the sampling was done at $80-85$ days after sowing (DAS).

Water potential of leaves was measured with the help of pressure chamber (Model 3005, Soil Moisture Equipment Corporation, Santa Barbara, CA, USA), between 8 AM to $10 \mathrm{AM}$ during sunny days and the osmotic potential ( $\Psi$ s) of leaves and roots was determined using vapour pressure osmometer (Model 5100-B, Wescor, Logan, USA). Whereas, the relative water content (RWC) of leaves and roots was measured according to Weatherley (1950) method.

\section{Results and Discussion}

The water potential $\left(\Psi_{w}\right)$ of leaves and osmotic potential of leaves and roots decreased significantly in both the genotypes. Whereas, chickpea variety HC-3 showed more negative values $\Psi_{w}$ of leaves i.e. from -0.42 to -0.49 $\mathrm{MPa}$ as compared to -0.44 to $-0.54 \mathrm{MPa}$ in CSG-8962, respectively (Table 1).

The osmotic potential $\left(\Psi_{\mathrm{s}}\right)$ of leaves decreased from -0.58 to -1.12 and -0.72 to $-1.28 \mathrm{MPa}$ in HC-3 and CSG-8962, respectively (Table 2). Similarly, osmotic potential $\left(\Psi_{\mathrm{s}}\right)$ of roots also decreased from -0.56 to -0.81 in HC-3 and 0.58 to $-0.88 \mathrm{MPa}$ in CSG-8962, respectively with an increase in salinity levels over control to $6.0 \mathrm{dS} \mathrm{m}^{-1}$ (Table 3). Relative water content (RWC) of leaves also decreased significantly from 9.2 to $28.8 \%$ and 8.5 to $24.5 \%$ in CSG8962 and HC-3 genotypes respectively (Figure 1). Similarly, significant decrease from 5.5 to $29.5 \%$ and 4.3 to $23.2 \%$ in relative water content in roots was also observed in both the chickpea varieties i.e. CSG-8962 and HC-3, respectively with increasing saline irrigation levels (Figure 2). 
Table.1 Effect of saline irrigation on water potential in leaves of chickpea genotypes

\begin{tabular}{|c|c|c|c|c|c|}
\hline EC $_{\text {iw }}$ & Control & $\mathbf{2}$ & $\mathbf{4}$ & $\mathbf{6}$ & Mean \\
\hline HC-3 & 0.42 & 0.44 & 0.45 & 0.49 & 0.45 \\
\hline CSG-8962 & 0.44 & 0.45 & 0.46 & 0.54 & 0.48 \\
\hline Mean & 0.43 & 0.44 & 0.46 & 0.51 & \\
\hline CD at 5\% & \multicolumn{3}{|c|}{ Genotype $=0.01$, Salinity $=0.02$, Genotype x Salinity = NS } \\
\hline
\end{tabular}

Table.2 Effect of saline irrigation on osmotic potential in leaves of chickpea genotypes

\begin{tabular}{|c|c|c|c|c|c|}
\hline EC $_{\text {iw }}$ & Control & $\mathbf{2}$ & $\mathbf{4}$ & $\mathbf{6}$ & Mean \\
\hline HC-3 & 0.58 & 0.87 & 0.98 & 1.12 & 0.89 \\
\hline CSG-8962 & 0.72 & 0.97 & 1.09 & 1.28 & 1.01 \\
\hline Mean B & 0.65 & 0.92 & 1.03 & 1.20 & \\
\hline CD at 5\% & \multicolumn{3}{|c|}{ Genotype = $=.01$, Salinity $=0.02$, Genotype x Salinity = 0.03} \\
\hline
\end{tabular}

Table.3 Effect of saline irrigation on osmotic potential in roots of chickpea genotypes

\begin{tabular}{|c|c|c|c|c|c|}
\hline EC $_{\text {iw }}$ & Control & $\mathbf{2}$ & $\mathbf{4}$ & $\mathbf{6}$ & Mean \\
\hline HC-3 & 0.56 & 0.58 & 0.75 & 0.81 & 0.67 \\
\hline CSG-8962 & 0.58 & 0.68 & 0.8 & 0.88 & 0.73 \\
\hline Mean & 0.57 & 0.63 & 0.77 & 0.84 & \\
\hline CD at 5\% & \multicolumn{2}{|c|}{ Genotype = 0.01, Salinity $=0.02$, Genotype x Salinity = 0.03} \\
\hline
\end{tabular}

Fig.1 Effect of saline irrigation on relative water content (RWC \%) in leaves of chickpea genotypes

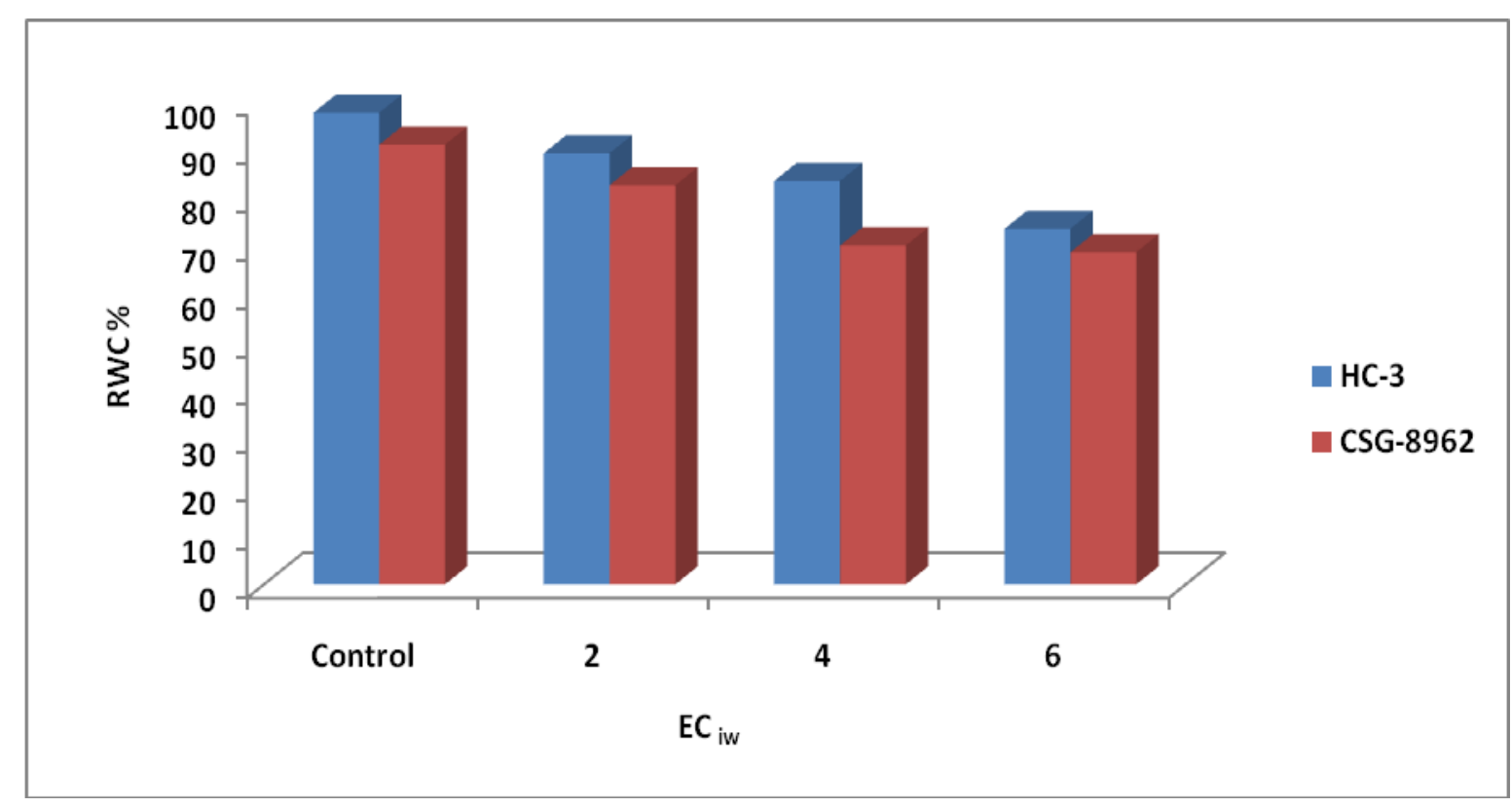


Fig.2 Effect of saline irrigation on relative water content (RWC \%) in roots of chickpea genotypes

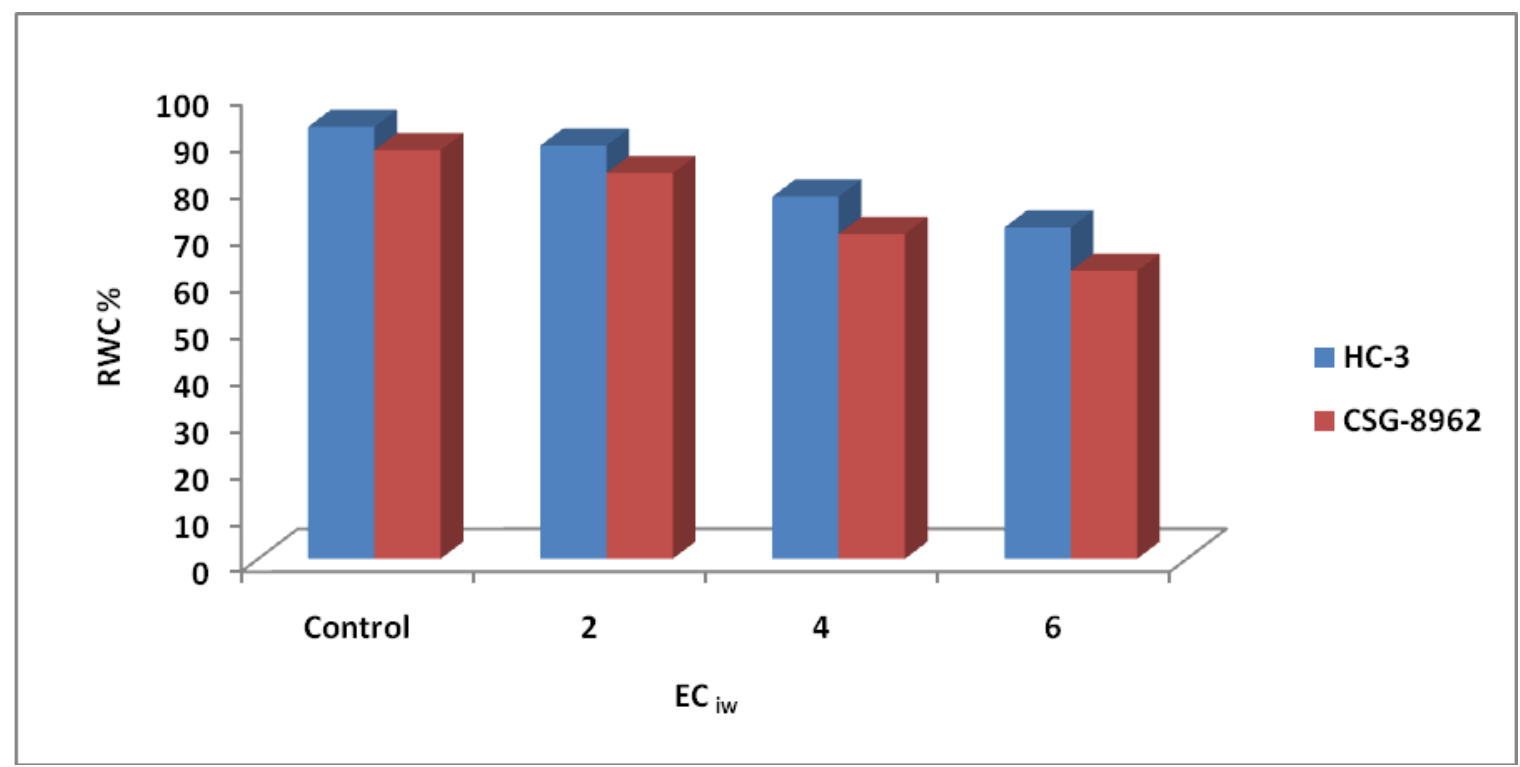

The possible reason for decreasing water and osmotic potential may be that the availability of water to the growing tissue becomes a limiting factor under saline conditions even in the presence of moisture in the soil resulting in what is termed as "Physiological drought". Water uptake by plants hence, attains importance under saline conditions. Plants cope up salinity by lowering their osmotic potential through accumulation of ions and compatible organic solutes. This is accompanied by a decline in water potential. Degree of decline in $\psi_{\mathrm{w}}$ and $\psi_{\mathrm{s}}$ depends upon the salinity resistance status of crop genotypes and accordingly these are able to absorb water from the rhizosphere (Singh, 2010). Salinity is one of the major stress which adversely affect many physiological and biochemical processes like ionic imbalance, water status, carbon allocation and its utilization (Zhu, 2001), lipid peroxidation and enzyme levels (Nandwal et al., 2000) which culminate in yield reduction. Salt stress causes increase in osmotic potential of rooting medium as result of high solute content (Geetanjali and Neera, 2008), subsequently the water potential and osmotic potential decreased and cell turgor pressure increased with increased salinity (Parida and Das, 2005). Hence, it can be concluded that there was more reduction in water potential and osmotic potential in CSG8962 as compared to HC-3. Therefore, HC-3 showed comparatively better performance than CSG-8962 on the basis of various physiological traits related to plant water relations under saline irrigation conditions. Hence, it can be recommended that the variety HC-3 could be further used in crop improvement programmes of salinity tolerance of chickpea.

\section{References}

Arefian, M., Vessal, S. and Bagheri, A. 2014. Biochemical changes and SDS-PAGE analyses of chickpea (Cicer arietinum L.) genotypes in response to salinity during the early stages of seedling growth. Journal of Biological and Environmental Science, 8(23): 99109.

Flowers, T.J., Gaur, PM, Gowda, C.L.L., Krishnamurthy, L., Samineni, S., Siddique, K.H.M., Turner, N.C., Vadez, 
V., Varshney, R.K. and Colmer, T.D. 2010. Salt sensitivity in chickpea. Plant Cell and Environment, 33: 490-509.

Geetanjali, M. and Neera, G. 2008. Salinity and its effects on the functional biology of legumes. Acta Physiologiae Plantarum, 30: 595-618.

Kandil, A.A., Arafa, A.A., Sharief, A.E. and Ramadan, A.N. 2012.Genotypes differences between two mungbean varieties in response to salinity stress at seedling stage. International Journal Agriculture, 4(7): 278-283.

Kukreja, S., Nandwal, A.S., Kumar, N., Sharma, S.K., Sharma, S.K., Unvi, V.K. and Sharma, P.K. 2005. Plant water status, $\mathrm{H}_{2} \mathrm{O}_{2}$ scavenging enzymes, ethylene evolution and membrane integrity of Cicer arietinum roots as affected by salinity. Biologia Plantarum, 49: 305-308.

Nandwal, A.S., Godara, M., Kamboj, D.V., Kundu, B.S., Mann, A., Kumar, B. and Sharma, S.K. 2000. Nodule functioning in trifoliate and pentafoliate mungbean genotypes as influenced by salinity. Biologia Plantarum, 43: 459-462.

Parida, A.K. and Das, A.B. 2005. Salt tolerance and salinity effect on plants: a review. Ecotoxicology and Environmental Safety, 60: 324-349.

Roy, F., Boye, J. and Simpson, B. 2010. Bioactive proteins and peptides in pulse crops: Pea, chickpea and lentil. Food Research International, 43: 432-442.

Singh, S. 2010. Effect of saline irrigation on anatomical, reproductive and physiological aspects of chickpea (Cicer arietinum L.) genotypes $\mathrm{Ph} \mathrm{D}$. Thesis, CCS HAU, Hisar, India.

Tekeoglu. M., Santra, D.K., Kaiser, W.J. and Muehlbauer, F.J. 2000. Ascochyta blight resistance in three chickpea recombinant inbred line populations. Crop Science, 40: 1251-56.

Weatherley, P.E. 1950. Studies on the water relations of the cotton plant. The field measurement of water deficit in leaves. New Phytologist, 40: 81-97.

Wright, P.R., Morgan, J.M. and Jessop, R.S. 1997. Turgor maintenance by osmo regulation in Brassica napus and $B$. juncea under field condition. Annals of Botany, 80: 313-319.

Zhu, J.K. 2001. Plant salt tolerance. Trends in Plant Science, 6: 66-71.

\section{How to cite this article:}

Neelam and Neeraj Kumar. 2018. Physiological Responses of Chickpea Genotypes under Varying Salinity Levels. Int.J.Curr.Microbiol.App.Sci. 7(01): 2086-2090. doi: https://doi.org/10.20546/ijcmas.2018.701.251 